\title{
Effect of learning strategies and anxiety of learning mathematics
}

\author{
Rusmono \\ Jakarta State University, Indonesia (email@ rusmono.com)
}

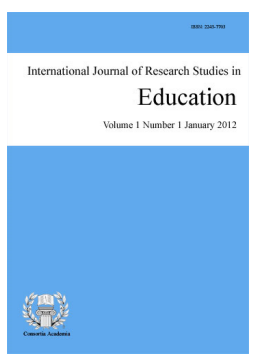

Accepted: 7 January 2015 Online ISSN: 2243-7711

OPEN ACCESS

\section{Abstract}

The research is intended to discover the effect of instructional strategies and math anxiety on learning outcomes in mathematics. Factorial design $2 \times 2$ was employed in order to answer the research question how the effect of the instructional strategies and math anxiety on learning outcomes in mathematics. It implies that there is no single instructional strategy that gives better result on learning outcomes in mathematics for all students with the different math anxieties. Based on this research findings mathematics vocational teachers in the field of technology and industry should apply several instructional strategies to serve students with different math anxieties.

Keywords: learning strategy; math anxiety; learning outcomes; instructional strategy 


\section{Effect of learning strategies and anxiety of learning mathematics}

\section{Introduction}

Learning strategies that have been developed by a math teacher at SMK result in a contribution to the extent of checking students' reception and interpretation of mathematical concepts and procedures, causing anxiety on students, especially every time they do the tasks as well as will take the test. It appears that the role of learning strategies in mathematics learning activities is importan. PBL learning strategy offers the freedom of students in the learning process. The problem in this study were:

$>\quad$ Are there differences in learning outcomes between students who take mathematics learning strategy PBL with students who take Expository learning strategy?

$>\quad$ Are there differences in mathematics learning outcomes of students who have high levels of math anxiety among the strategies followed by the PBL learning and teaching strategies that follow Expository?

$>$ Are there differences in mathematics learning outcomes of students who have low levels of math anxiety among which followed the PBL and learning strategy that follows Expository learning strategy?

$>\quad$ Is there an interaction effect between learning strategy and the level of mathematics anxiety on math learning outcomes?

\section{Methods}

The research was conducted at the Central Jakarta SMK 39 semester 2008-2009 school year. The method used is an experimental method with a $2 \times 2$ factorial design. The dependent variable in this study is a result of students' mathematics learning. The independent variable is the treatment of learning strategies, which can be divided into two groups, namely PBL as a learning strategy and the experimental group and Expository teaching strategy as a control group. Intervention in the form of the independent variable is the variable attribute mathematics anxiety. Data collection used a test for math anxiety, which has been tested again and the test results to learn metematika. For hypothesis testing is done using Analysis of Variance technique (ANOVA) followed by a two-lane Scheffe test.

\section{Results}

Based on the analysis of data by ANOVA two lines of evidence point hypothesis in this study can be explained in the following description. First, there are differences in the overall learning outcomes of students who take math learning strategies with PBL higher mathematics achievement than students who take Expository learning strategies. From the calculations, the average score for a group of students who take the PBL learning strategies of 24.12, while the group of students who take the Expository learning strategies have an average score of 21.90. ANOVA calculation results indicate that the two pathways value $\mathrm{Fh}=40.67$ which was greater than the value of $\mathrm{Ft}=3.91$ for significance level $\alpha=0.05$ or $(\mathrm{Fh}>\mathrm{Ft})$. This means that $\mathrm{H}_{0}$ rejected and $\mathrm{H}_{1}$ accepted, so there is a significant difference between the application of learning strategies with PBL with Expository learning strategies on learning outcomes of mathematics. Scheffe test results' obtained at $\mathrm{Ft}=41.07$ and $\mathrm{Fh}=2.70$ at the significance level $\alpha=0.05$. Turns $\mathrm{Fh}>\mathrm{Ft}$ so that $\mathrm{H}_{0}$ rejected and $\mathrm{H}_{1}$ accepted. It can be concluded that, overall learning outcomes of students who take math learning strategies with PBL higher than students who take the expository teaching strategies. 
Second, the results of the group of students learning mathematics with high math anxiety and learning strategies followed by PBL has an average score of 25.68, while a group of students who have high math anxiety and follow Expository learning strategies have an average score of 18.38. Scheffe test results' obtained at $\mathrm{Fh}=$ 197.37, while for $\alpha=0.05$ significance level of 2.80 and a significance level of 0.01 to 4.22 magnitude. It turned out better value greater than the significance level of 0.05 and a significance level of 0.01 , so $\mathrm{H}_{0}$ rejected and $\mathrm{H}_{1}$ accepted. Means for groups of students who have high math anxiety, students who take learning strategies with learning outcomes PBL have higher math than students who take Expository learning strategies.

Third, mathematics learning outcomes for students who have low levels of math anxiety yangmengikuti PBL learning strategies with lower than students who take Expository learning strategies. From the calculations, the average score of the group of students who have low math anxiety and learning strategies followed by PBL has amounted to 21.72, while the group of students who have math anxiety low and follow the expository instructional strategies have an average score of 23.89. Based on Scheffe test 'was obtained for $F \mathrm{~F}=18.84$, while for the 0.05 significance level of 2.80 and a significance level of 0.01 to $\mathrm{Ft}=4.22$ magnitude. It turned out better value smaller than the significance level of 0.05 and a significance level of $0.01, \mathrm{so}_{0}$ accepted and $\mathrm{H}_{1}$ rejected. Means for groups of students who have low math anxiety, students who take learning strategies with learning outcomes PBL had lower math than students who take Expository learning strategies

Fourth, there is an interaction effect between strategoi learning and math anxiety on math learning outcomes. The test results show that the second hypothesis, the results of students' mathematics learning with high math anxiety and learning strategies followed by PBL higher than students who had high math anxiety and learning strategies Expository follow. The third hypothesis test results showed that students' mathematics learning outcomes that have low math anxiety and learning strategies followed by PBL lower than students who had low math anxiety and learning strategies Expository follow.

Results of the second and third hypothesis test indicates the interaction between learning strategy math anxiety in their influence on mathematics learning outcomes. ANOVA calculation results confirm these indications, because of the calculation obtained $\mathrm{Fh}=176.99$ which was higher than the value of $\mathrm{Ft}=3.91$ for significance level $\alpha=0.05$ and also larger than the significance level $\mathrm{Ft}=6.90$ for $\alpha=0.01$ or Fh $>$ Ft. This means that $\mathrm{H}_{0}$ rejected and $\mathrm{H}_{1}$ accepted, so it can be concluded that, there is a highly significant interaction effect between learning strategies and mathematics anxiety in their influence on mathematics learning outcomes.

\section{Findings}

Testing the four hypotheses proposed in this study has yielded details of the test results the following hypothesis. First, the results of the first hypothesis test has been successfully reject the null hypothesis that states there is no difference in mathematics achievement between groups of students who take lessons with and PBL learning strategies with groups of students who take Expository learning strategies. So overall there are differences in mathematics achievement between students who take the PBL learning strategies with students who take Expository learning strategy, ie learning outcomes of students who take math learning strategies with PBL higher mathematics achievement than students who take Expository learning strategies. Second, the results of the second hypothesis test successfully reject the null hypothesis that states there is no difference in students' mathematics learning outcomes that have high math anxiety, among the group of students who take learning strategies with PBL and the group of students who take Expository learning strategies. So that there are differences in mathematics learning outcomes of students who have high levels of math anxiety among the following learning strategy with the following PBL Expository learning strategy, ie learning outcomes of students who take math learning strategies with PBL higher learning outcomes than students who take math learning strategies Expository. Third, the results of the third hypothesis test successfully reject the null hypothesis that states there is no difference in students' mathematics learning outcomes that have low math anxiety, among the group of students who take learning strategies with PBL and the group of students who take Expository learning strategies. So that there are differences in mathematics learning outcomes of students who 
have low levels of math anxiety among students who take learning strategy with the following PBL Expository learning strategy, ie learning outcomes of students who take math learning strategies with PBL inferior learning outcomes of students who take math learning strategies expository. Fourth, the results of the fourth hypothesis testing has been successfully reject the null hypothesis that states there is no interaction between PBL and learning strategies with math anxiety in their influence on mathematics learning outcomes. Thus the fourth hypothesis test showed that there was an interaction between learning strategies and mathematics anxiety in their influence on mathematics learning outcomes.

\subsection{Limitations}

First, SMK 39 Jakarta Students come from different economic backgrounds, family backgrounds, and neighborhoods. The similarity of the characteristics of students still require further study. Second, control of mathematical skills for research subjects only include the variable learning strategies and mathematics anxiety. The results can be influenced by other variables outside the predefined variables in this study. Other variables, such as: intelligence, interest, motivation, learning styles, learning environment, reasoning ability and others not controlled. Third, this study also does not take into account the influence of early mathematical skills of students who became the object of research, so it can not be known a gain score. Fourth, the mathematical material used in this study only mathematics X class vocational courses electronics and technology industries, namely: matrices, linear programming, and mathematical models fit the book Education Unit Level Curriculum (SBC) SMK 39 Jakarta in 2007.

\subsection{Recommendations}

Suggestions To Teachers - With the results of these studies as described earlier discussions, the SMK and the technology industry in particular, it is recommended that:

$>\quad$ Implementing learning using learning strategies with PBL as one of the alternatives in the learning of mathematics. With learning strategy and PBL learning achievement of mathematics as a whole proved to be more successful than Expository learning strategies. Learning strategies with more PBL allows terbelajarkannya mathematics as a whole. In other words, students are actively involved in the learning process, practice solving problems through discussions and access information from a variety of learning resources.

$>\quad$ In designing and developing mathematical learning programs, teachers need to pay attention to the characteristics of students who received math learning program. To students who have a high math anxiety would be more appropriate if the following learning strategies with PBL, whereas for students who have low math anxiety is more apt to follow the Expository learning strategies. To that end, teachers are expected to be more careful in identifying the students' characteristics, the characteristics of the subject matter, and competencies to be achieved, in order to select and implement learning strategies more appropriate mathematics.

$>$ Teachers, should strive to improve its ability to use learning strategies with PBL. This is because the PBL learning strategy is relatively new and unfamiliar teachers use it.

$>\quad$ Do the math student learning outcomes assessment and continuous continuously. Therefore, assessment tools can be developed in the form of a test or non-test with a variety of in accordance with the characteristics of the object being evaluated and the objectives to be achieved.

To the suggestion Principal - A process of innovation in the field of education, requiring innovation support system where it will be applied. To support the process of change in the paradigm of teaching in schools in accordance with the demands of science and technology development, the head of technology and industrial vocational schools are expected to provide opportunities for teachers to undertake various reform efforts in 
learning mathematics, especially in adopting strategies for learning with PBL as an alternative learning strategy mathematics in school. To implement this decision, in addition to providing the opportunity for teachers, also need support from the principal and school superintendent. Renewal process that occurs at the level of the class, will depend on the opportunities provided to teachers to implement the learning process seriously, as a framework of overall achievement of learning objectives.

Advice To Other Researchers - Suggested to other researchers to develop further research related to mathematics learning strategy that is more likely to improve students' mathematics learning outcomes, and assess other learning strategies as well as taking into account the characteristics of student learning outcomes related to mathematics. In connection with that, it is necessary to study the following matters: a) conduct another investigation by looking at the mathematics learning outcomes not only in terms of content, but also in terms of process and mathematics attitude, b) control the independent variables beyond the variables examined more closely, such as: initial test scores, student interest and motivation, learning styles, ways of thinking, talent and intelligence, c) conducted a study on the re-location or a different school levels, to determine whether the results of research conducted by the same research this, d) custodian chose mathematics teacher with sex or different levels of education. 
